\title{
THE INFLUENCE OF WORLD STOCK INDEX, BI RATE AND FED RATE THROUGH IHSG ON EXCHANGE RATES IN INDONESIA FOR THE PERIOD OF 2006-2015
}

\author{
Kamaruddin Rifka Ilham*, Saskara Ida Ayu Nyoman \\ Faculty of Economics and Business, University of Udayana, Bali, Indonesia \\ *E-mail: rifka.ilham29@gmail.com
}

\begin{abstract}
This study aims to analyze external factors, namely the influence of the Nikkei 225 index and the Dow Jones index on the IHSG and the exchange rate in Indonesia for the period 20062015; and analyze the influence of Indonesian and foreign government policies through the $\mathrm{BI}$ rate and the Fed Rate on the $\mathrm{JCl}$ and the exchange rate in Indonesia for the period 20062015. The data analysis technique used is path analysis. The results showed that the Nikkei 225 index (X1), the Dow Jones index (X2), the $\mathrm{BI}$ rate $(\mathrm{X} 3)$ and the Fed rate (X4) had a significant effect on the IHSG (Y1) in Indonesia in 2006-2015 and the Nikkei 225 index (X1), Dow Jones index (X2), BI rate (X3), Fed rate (X4), and IHSG (Y1) have a significant effect on the exchange rate (Y2) in Indonesia in 2006-2015.
\end{abstract}

\section{KEY WORDS}

Nikkei 225 index, Dow Jones index, BI rate, Fed rate, IHSG, exchange rate.

The increasingly widespread globalization of world markets brings the consequences of international market liberalization. This condition makes it difficult to control monetary pressure on the world economy. Under these conditions, the process of price formation (exchange rates, interest rates, stock indices, commodity prices, etc.) is also determined by the economies of other countries. The monetary crisis in several Latin American countries, Eastern Europe and Asia including Indonesia is inseparable from the process of market globalization.

Measures to reduce the pressure of Rupiah depreciation, monetary policies have taken cover a variety of things, including widening the intervention band, restrictions on foreign exchange transactions by banks, changes in the exchange rate system and tightening banking liquidity. Various measures have not fully succeeded in holding back the rate of depreciation of the rupiah because the crisis in a short period has developed from the original monetary crisis to an economic crisis, a socio-cultural crisis, and a political crisis so that it becomes a multidimensional crisis (Bank Indonesia, 1998).

At that time the rupiah depreciation continued until it had reached $600 \%$ in less than one year, from Rp. 2,350, - to Rp. 16,000 per 1 USD. Meanwhile, interbank interest rates had reached $60 \%$ per year. Another result of the distribution of goods had slowed awaiting the stability of prices and security, especially due to demonstrations and destruction of trade centers by the masses in various cities. Until the end of this period, economic growth declined by $13.7 \%$, prices of goods surged, companies went out of business, unemployment increased and several public facilities and trade centers were heavily damaged. Since July 1997, the Rupiah has depreciated against foreign currencies, especially the USD. Thus the rapid process of the decline in the Rupiah occurred, causing market panic. The various policies pursued by Bank Indonesia did not succeed in stopping the rate of decline in the exchange rate, both in the form of widening the intervention band, tightening banking liquidity and the morale of the situation to market participants.

The mechanism to save foreign exchange reserves than on August 14, 1997, the intervention band was released and subsequently Indonesia implemented a floating exchange rate policy until now. This system is then confirmed by Law No. 23 and 24 of 1999. The Act stipulates that the exchange rate system in Indonesia is determined by the Government after hearing recommendations from Bank Indonesia. This is done because the 
exchange rate system will have a very broad impact, not only on monetary and financial sector activities but also on real economic activities (Bank Indonesia, 1998).

The 2008 economic turmoil was mainly triggered by rapid innovation in financial products such as securities practices and credit default swaps. This is exacerbated by property speculation and inaccurate credit increases. In both cases, the development of the crisis spread to other continents and in a relatively short period became a global crisis because of its contagious effect amid a globally integrated financial system and rapid information distribution (Raz et al, 2012).

The weakening of the US dollar accompanied by depressed global financial markets which triggered the diversion of investment from financial markets to commodity markets which subsequently pushed up international commodity prices. High international commodity prices put pressure on global inflation. The behavior of foreign investors who tend to avoid risks had the opportunity to encourage capital outflows from the domestic financial market. On the stock market, foreign capital outflows drive the weakening of the stock market's performance.

The role of the foreign exchange rate (foreign exchange) for developing countries such as Indonesia is very important, especially for hard currencies such as the US Dollar (USD) and the Japanese Yen (JPY). The importance of this foreign exchange rate, because as a country that is conducting economic development, the foreign exchange rate will be directly related to foreign trade, investment, and even direct links with foreign debt (LN) which is the source of development funds (Kuncoro, 2015).

The capital market has a very important role in a country's economy. Funding support from the capital market has proven to have a positive impact on economic development in many countries. With the adoption of open economic policies and free markets accompanied by rapid technology, investors make it easy to access capital markets that exist throughout the world. The fact that states that the capital market is one indication of the health of a country's economy, suggests how important the condition of capital markets in a country (Gupta et al, 1999).

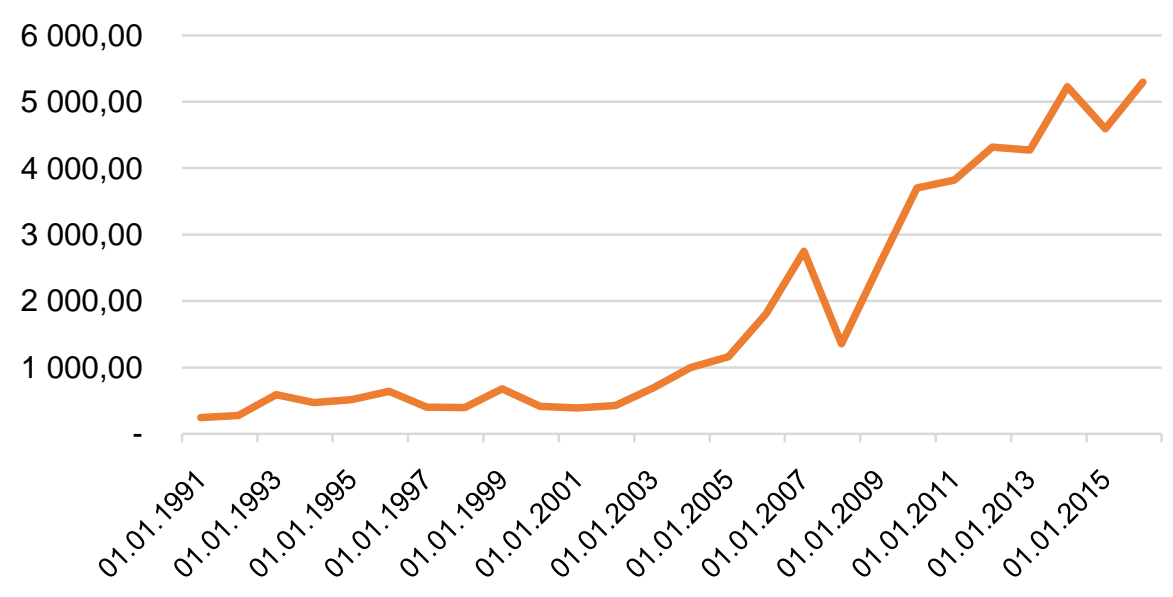

Figure 1 - IHSG 1990-2015 (Source: Reuters)

Investment is an injection for a country's economic development, as well as determining the dynamics of development that can directly improve the welfare of society. If the investment goes well, the economy will also improve, as long as the investment process produces output efficiently. As seen in Figure $1 \mathrm{JCl}$ has continued to increase quite dramatically since 2000 , in 2000 the $\mathrm{JCl}$ was in the position of 424.95 to $2,745.83$ in 2007 or an increase of $560 \%$. Although the high index growth was hampered in 2008 due to the global crisis that affected the performance of the stock markets throughout the world including the Indonesia stock exchange which experienced an index decline of $50.64 \%$. The 
Jakarta Composite Index (JCl) again experienced an increase from 2009 to 2015, which was $81 \%$.

Global economic conditions greatly affect the economic conditions of a country. It can be seen in Figure 2. exchange rate conditions and the Jakarta Composite Index (JCl) experienced turmoil that influenced each other. In 2008 when IHSG experienced a decline, it was followed by a weakening of the Rupiah. This is due to the global crisis that is felt by almost all countries, especially Indonesia which has international trade relations with the United States. Capital outflows where investors want to save funds in the place to save heaven currency in other places, such as Japan. Besides, foreign interest rates also affect the IHSG and the exchange rate, namely the US interest rate (Fed Rate).

The shift of funds from country to country is one of the factors that quite influences the direction of capital flows. The placement of funds in a country considers many things, namely fundamental factors, the direction of the economy and the direction of a country's policy. Indonesia is a developing country which of course also depends on developed economies such as America and Japan. Because these two countries are destination countries for one of Indonesia's export destinations and of course these two superpowers' exchanges are in the spotlight and size of the country's economy. The American market is called the Dow Jones Index and the Japanese stock market is called the Nikkei Index.

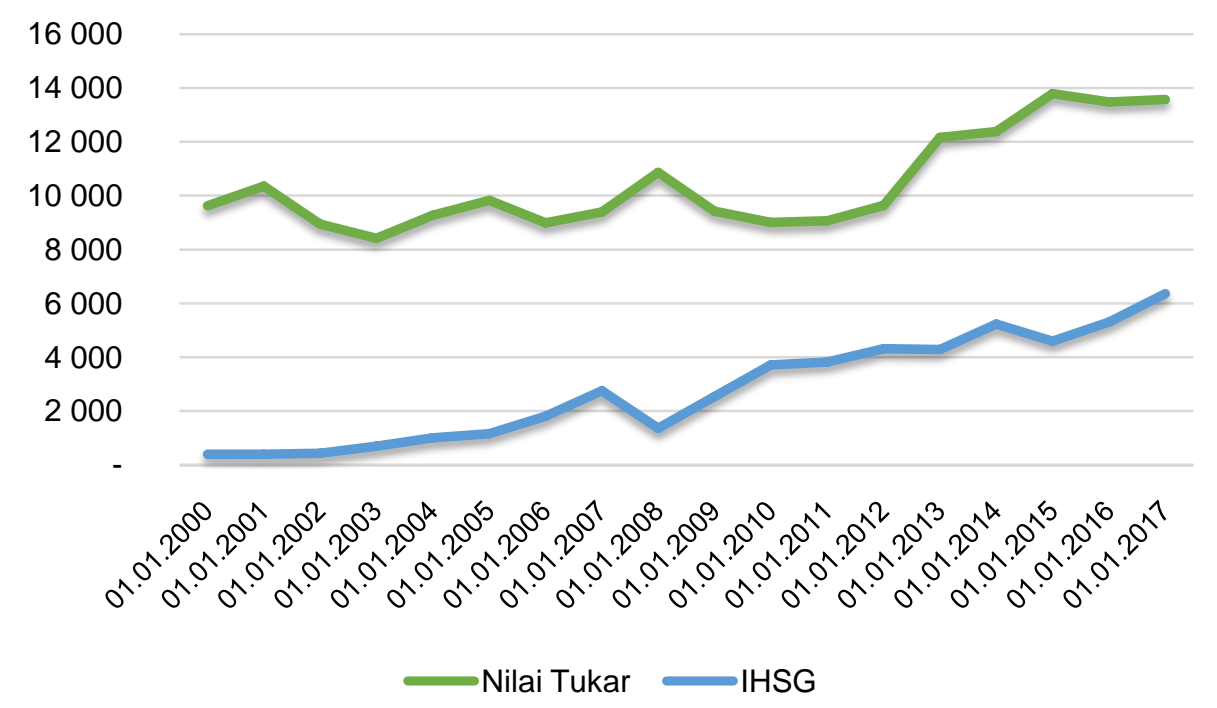

Figure 2 - Exchange Rates and The Composite Of Stock Price Index for the period 2000-2017 (Source: Reuters)

Ibrahim 2000, asserted that changes in stock prices can affect capital inflows and outflows, which will result in changes in currency values. Subsequent research Ibrahim (2002) found that in multivariate testing there was a one-way causality from the stock market index to the exchange rate. Furthermore, the exchange rate and stock index are influenced by money supply and vice versa.

The importance of the government's role in taking a monetary policy mechanism is very necessary to control an economy to a better condition. Maintaining economic stability is the main task of the government to maintain inflation and exchange rate stability through the interest rate mechanism.

Sitinjak and Kurniasari, 2003: 35 explained, "Depreciation of the rupiah exchange rate against foreign currencies, especially the US dollar, has a negative influence on the economy and capital markets". According to Appa 2014, the depreciation of the value of the rupiah against the US dollar caused the shares of import-oriented companies to decline and impacted the decline of investors' interest to invest in the capital market.

Arifin 1998, said that monetary tightening encouraged an increase in interest rates that could have an impact on the appreciation of the rupiah during the crisis. Warjiyo 1998, stated 
that the use of interest rates as an operational target of monetary policy is very good in suppressing the rupiah exchange rate.

The causality relationship between stock prices and exchange rates has received the attention of several researchers since the 1980s. Most of the empirical research in this regard has focused on the advanced level of economics. But emerging market economies are more vulnerable to volatility in the stock market and currency market because of their structural weaknesses. Understand the relationship between stock and foreign markets (Akdogul et All, 2016).

The author hereby considers the need to do a study to analyze how the relationship between market mechanisms that do not involve government intervention and mechanisms that involve government policy. First, the exchange rate flu notation is not only caused by domestic influences, but fundamental factors originating from abroad also influence the IHSG and Exchange Rates. Secondly, government policy is certainly an important factor in controlling the economy of a country in this study taking government policy for two countries namely Indonesia and the United States with the interest rate policy mechanism.

Based on the background of the above problems, several main points to be formulated in this study can be formulated 1) What is the effect of the Nikkei 225 index, the Dow Jones index, the $\mathrm{BI}$ rate and the Fed rate on the IHSG in Indonesia for the period 2006-2015? 2) What is the effect of the Nikkei 225 index, Dow Jones index, BI rate, Fed rate and IHSG on the exchange rate in Indonesia for the period 2006-2015? 3) Does the Nikkei 225 index, Dow Jones index, $\mathrm{BI}$ rate, and Fed rate indirectly influence the exchange rate through the IHSG for the period 2006-2015?

Based on the background and formulation of the problems outlined above, this study aims to 1) analyze the factors that affect the exchange rate either without going through government intervention namely the influence of foreign stock indexes or through government intervention through interest rate policies, 2) analyzing the influence of policies Indonesian and foreign governments, namely through the $\mathrm{BI}$ rate and the Fed Rate on the IHSG and the exchange rate in Indonesia for the period 2006-2015, 3) Analyzing the indirect effect of the Nikkei 225 index, the Dow Jones index, the $\mathrm{BI}$ rate and the Fed rate on the exchange rate through the IHSG in Indonesia for the period 2006-2015.

\section{CONCEPTUAL FRAMEWORK}

As a result of the globalization of the world economy, there was a phenomenon that occurred in developing countries such as Indonesia. This also happened to other countries such as Argentina 1994 and Turkey 2001. The Bapepam-LK Cointegration and Causality Study (2008) states that from this incident a clear pattern can be seen that in developing countries where market capitalization is still small the flow of foreign funds has the power to influence stock price movements.

In the case of emerging markets such as India, Pakistan, South Korea, and the Philippines, Abdalla and Murinde (1997) found that the exchange rate had a lead (effect) on stock prices. What is happening in the Philippines is the opposite, namely the price of shares that take the lead to the domestic currency. Research conducted by Ma and Kao (1990) also found that by using six-country data, appreciation had a negative effect on domestic share prices for export-dominated economies and had a positive effect on domestic stock price movements for imported-dominated economies.

The rising of the Nikkei 225 Index means that the performance of the Japanese economy is improving. As one of Indonesia's export destination countries, Japan's economic growth can drive Indonesia's economic growth through export activities and capital inflows, both direct investment and through the capital market (Sunariyah, 2006).

Nikkei 225 index which is a composite index of Japan's stock prices. Japan's economy greatly influences the rotation of the world economy. Supported with a value of US $\$ 2.6$ trillion in Gross Domestic Product in 2006, Japan's economy is the second-largest economy in the world. Therefore, stock indexes in Japan also greatly affect the movement of exchanges in the Asian region (Surbakti et al, 2011). 
The Dow Jones index is moving up, indicating the performance of the United States economy, in general, is in a good position. With good economic conditions, it will drive the Indonesian economy through exports and the capital market (Sunariyah, 2006). Capital flows entering the capital market will certainly influence changes in the Composite Stock Price Index (Ernayani et al, 2015).

Wangbangpo and Sharma (2002) found that exchange rates have a positive relationship with share prices in Indonesia, Malaysia, and the Philippines, conversely negatively in Singapore and Thailand. Ruhendi and Arifin (2003) conducted a study on the impact of changes in the rupiah exchange rate and the dow jones index on the New York Stock Exchange on the IHSG for the period February 1, 2001 to January 31, 2002 and concluded that changes in the rupiah exchange rate and the dow jones index had a significant effect on the price index joint stock. Chiarella and Gao (2004) state that the interest rate has a negative effect on market returns. Hooker (2004) in his research concluded that the interest rate has a negative effect on stock returns.

Nachrowi and Usman (2007) the influence of Dow Jones on IHSG indirectly illustrates the strong influence of the economic performance of the two countries on Indonesia. When America has good performance, Indonesia will also enjoy the performance. But when both of them have poor performance, it will also have a negative impact on Indonesia.

With the rise of the Dow Jones Index, the performance of the United States economy is improving. As one of Indonesia's export destination countries, economic growth in the United States can encourage Indonesia's economic growth through exports and capital inflows, both direct investment and through the capital market (Sunariyah, 2006)

Research on the effectiveness of interest rates in the context of rupiah stabilization carried out by Arifin (1998) suggests that monetary tightening encourages an increase in interest rates that can have an impact on the appreciation of the rupiah during the crisis. Warjiyo (1998) states that the use of interest rates as an operational target of monetary policy is very good in suppressing the rupiah exchange rate. Research on the relationship of inflation, interest rates, and money in circulation to the exchange rate conducted by Noor (2014) states that the interest rate and money in circulation have a relationship with the exchange rate.

Research on SBI interest rates has a significant effect on the stock price index on the Indonesia Stock Exchange conducted by Murtadho (2016), so does the interest rate (PBOC) which has a significant effect on the Shanghai Composite Index and the Reserve Bank of Australia (RBA) Interest Rate has a significant influence on the Australian Index Securities Exchange (ASX).

The research on interest rates on the value of the stock price index was conducted by Putri (2015) which stated that interest rates had a negative and significant effect on the composite stock price index. Ha In the same study conducted by Palatte (2014), the SBI interest rate has a negative and significant effect on the composite stock price index. Efni's research result (2013) states that deposit interest rates have a significant influence on the stock price index on the Indonesia stock exchange. Research on the Dow Jones Index and the Nikkei Index and interest rates on the IHSG conducted by Lestari (2015) states that interest rates have a negative and significant effect on the IHSG. Research conducted by Utami (2003) states that interest rates and exchange rates affect stock prices.

Any increase in interest rates set by the Federal Reserve or the Fed will have a major impact on financial markets and capital markets around the world, where investors will withdraw funds and make capital outflows to repatriate their funds for investment in deposits or deposits. This situation has caused turmoil in the money market and capital markets, especially in developing countries like Indonesia. The exchange rate of the currency against the US Dollar has decreased significantly which impacted the collapse of stock prices on the stock exchange floor even the Shanghai stock exchange had fallen to $70 \%$.

Changes in the Fed rate will affect foreign exchange rates, while currency exchange rates can affect share prices through the discount rate or expected future cash flow components or both. The amount of influence depends on the ability of the exchange rate to adjust changes in global interest rates. 
The framework of thinking is arranged according to the research problem which is based on theoretical studies with deductive thinking processes and empirical studies which are the results of previous research. The process of deductive thinking examines universal theories, and empirical studies are inductive to study something specifically to be generalized to obtain general conclusions.

The interrelationship between the research variables will be described in this section. Nikkei Index, Dow Jones Index, Bi Rate, Fed rate As those that affect the dependent variable. Composite stock price index (IHSG) as an intervening variable, and Exchange Rate as a variable that is influenced or dependent. This research framework shows how the influence of the dependent and intervening variables on the independent variable.

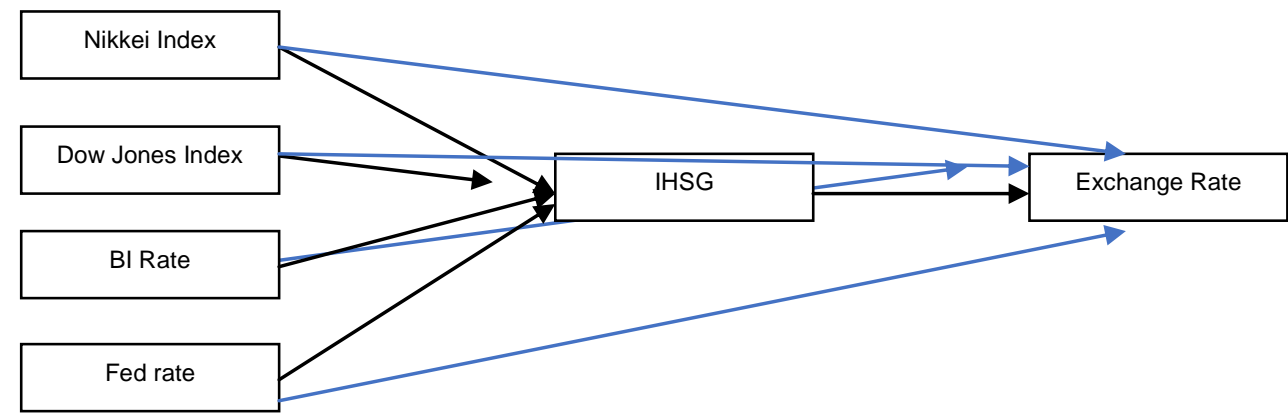

Figure 4 - Conceptual Framework

The International Fisher Effect Theory explains that foreign currencies will be appreciated when foreign interest rates are smaller than those of the home country (Madura, 2006: 315). Countries with relatively high-interest rates will cause the currency to depreciate. The International Fisher Effect shows the relationship between changes in the percentage of spots and differences in interest rates in capital markets between countries (Sartono, 2012: 148). This theory is closely related to the PPP theory because interest rates often collaborate with the inflation rate so it can be concluded that the differences in interest rates that occur in some countries are caused by the inflation rate.

Bakri Abdul Karim, M. Shabri, and S.A Abdul Karim (2008) suggested that the Indonesian capital market was integrated with the world capital market. This has the consequence that the movement of the Indonesian capital market will be influenced by the movement of the world capital market both directly and indirectly (M. Samsul, 2008).

Based on the description of the mindset above, the hypothesis in this study can be described as follows:

1. The Nikkei 225 index, the Dow Jones index, the $\mathrm{BI}$ rate, and the Fed rate affect $\mathrm{JCI}$ in Indonesia for the period 2006-2015;

2. The Nikkei 225 index, the Dow Jones index, the $\mathrm{BI}$ rate, the Fed rate, and the $\mathrm{JCl}$ affected the exchange rate in Indonesia for the period 2006-2015;

3. Nikkei index, Dow Jones index, BI rate, and Fed rate indirectly affect the exchange rate through the IHSG for the period 2006-2015.

The data analysis technique used to solve the problem in this study is a quantitative analysis technique using the help of the SPSS program. The analysis method used in this study is path analysis which is the development of linear regression analysis, so that regression analysis can be said to be a special form from path analysis. The location of the research is in the Unitary State of the Republic of Indonesia (NKRI) based on the importance of analyzing the factors affecting the exchange rate that stem from global economic turmoil both from foreign interest rates and world stock markets. The data used are secondary. This research applies path analysis where independent factors will influence the dependent factor through intervening variables. This study uses 6 variables consisting of one independent variable, namely the exchange rate (exchange rate), four independent variables namely the Nikkei 225 index, the Dow Jones index, the BI rate and the Fed Rate, and one intervening variable, the $\mathrm{JCl}$. 


\section{RESULTS AND DISCUSSION}

This research was conducted to determine and analyze the effect of the Nikkei 225 index, the Dow Jones index, the $\mathrm{BI}$ rate and the Fed rate on the exchange rate for the period 2006-2015 with the IHSG variable as intervening. The path coefficient in this study was obtained from the regression results with a simple regression method using the SPSS program on the equation model. This section will be solved in stages through a regression equation model to get the path coefficient. The equation model is as follows:

1) Model 1: The effect of the Nikkei 225 index (X1), the Dow Jones index (X2), the BI rate $(\mathrm{X} 3)$ and the Fed rate $(\mathrm{X} 4)$ on the $\mathrm{JCl}(\mathrm{Y} 1)$.

2) Model 2: Effect of Nikkei 225 index (X1), Dow Jones index (X2), BI rate (X3) and Fed rate (X4) and IHSG (Y1) on Exchange Rates (Y2).

Equation 1 testing was conducted to see the effect of the Nikkei 225 index, the Dow Jones index, the BI rate and the Fed rate on the IHSG for the period 2006-2015 which was carried out using the SPSS program. Then the test results will be presented in tables 1-2:

Table 1 - Model Summary Results Effects of the Nikkei 225 index, Dow Jones index, BI rate and Fed rate on the CSPI for the period 2006-2015

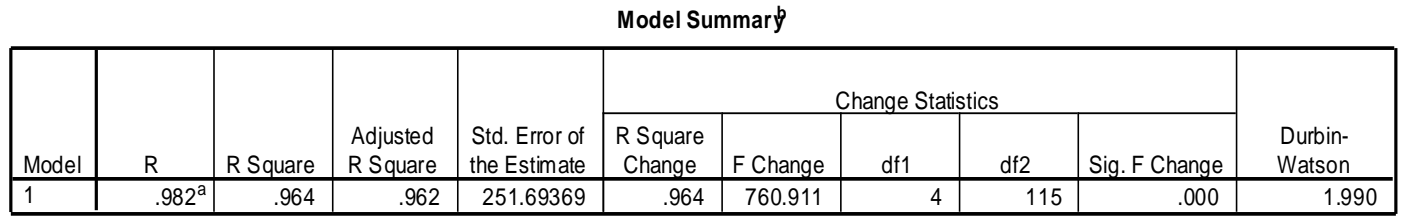

a. Predictors: (Constant), Fed Rate, Dow Jones, BI Rate, Nikkei

b. Dependent Variable: IHSG

Source: Processed Raw Data.

Table 2 - Coefficients Results The effects of the Nikkei 225 index, the Dow Jones index, the BI rate and the Fed rate on CSPI in Indonesia for the period 2006-2015

\begin{tabular}{|c|c|c|c|c|c|c|c|c|}
\hline \multicolumn{9}{|c|}{ Coefficients $^{a}$} \\
\hline \multirow{2}{*}{\multicolumn{2}{|c|}{ Model }} & \multicolumn{2}{|c|}{$\begin{array}{l}\text { Unstandardized } \\
\text { Coefficients }\end{array}$} & \multirow{2}{*}{$\begin{array}{c}\begin{array}{c}\text { Standardized } \\
\text { Coefficients }\end{array} \\
\text { Beta }\end{array}$} & \multirow[b]{2}{*}{$\mathrm{t}$} & \multirow[b]{2}{*}{ Sig. } & \multicolumn{2}{|c|}{ Collinearity Statistics } \\
\hline & & B & Std. Error & & & & Tolerance & VIF \\
\hline & (Constant) & 267.177 & 223.045 & & 1.198 & .233 & & \\
\hline & Nikkei & -.089 & .017 & -.253 & -5.157 & .000 & .132 & 7.590 \\
\hline & Dow Jones & .433 & .020 & .912 & 21.668 & .000 & .179 & 5.594 \\
\hline & BI Rate & -15270.3 & 2268.424 & -.200 & -6.732 & .000 & .358 & 2.797 \\
\hline & Fed Rate & -19383.9 & 2032.278 & -.257 & -9.538 & .000 & .435 & 2.301 \\
\hline
\end{tabular}

a. Dependent Variable: IHSG

Source: Processed Raw Data.

Based on the results of Table 1 and Table 2, the regression equation model can be arranged as follows:

$$
\begin{gathered}
e_{1}=\sqrt{1-R^{2}}=\sqrt{1-0,964}=0,036 \\
Y_{1}=-0,089 X_{1}+0.433 X_{2}-15.270,3 X_{3}-19.383,9 X_{4}-0,036
\end{gathered}
$$

Wjere:

$Y_{1}=$ IHSG;

$\mathrm{X}_{1}=$ Nikkei 225 Index;

$\mathrm{X}_{2}=$ Dow Jones Index;

$\mathrm{X}_{3}=\mathrm{BI}$ rate;

$\mathrm{X}_{4}=$ Fed rate. 
Table 2 shows that the Nikkei 225 index is sig. $0.000<0.05$ indicates that the Nikkei 225 index has a significant effect and has a negative effect on the IHSG. The Dow Jones index with a sig value of $0.000<0.05$ indicates that the Dow Jones index has a significant effect and has a positive influence on the IHSG. BI rate with sig. $0.000<0.05$ indicates that the $\mathrm{BI}$ Rate has a significant effect on and has a negative effect on the IHSG. Whereas the Fed Rate with sig. $0.000<0.05$ indicates that the Fed Rate has a significant effect on and has a negative effect on the IHSG.

The influence of the Nikkei 225 index, the Dow Jones index, the BI rate, the Fed rate, and the $\mathrm{JCl}$ on the exchange rate in Indonesia for the period 2006-2015

Equation 2 testing was conducted to see the effect of the Nikkei 225 index, the Dow Jones index, the $\mathrm{BI}$ rate, the Fed rate, and the IHSG on the exchange rate for the period 2006-2015 conducted using the SPSS program. Then the test results will be presented in tables 3 and 4 :

Table 3 - Model Summary Results Effects of the Nikkei 225 index, Dow Jones index, BI rate, and Fed rate and IHSG on exchange rates in Indonesia for the period 2006-2015

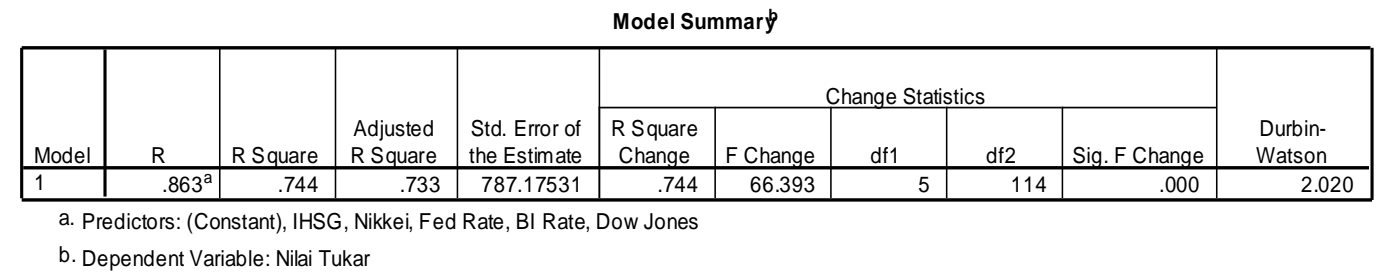

Source: Processed Raw Data.

Table 4 - Coefficients Results The effect of the Nikkei 225 index, Dow Jones index, BI rate, and Fed rate and IHSG on the exchange rate in Indonesia for the period 2006-2015

\begin{tabular}{|c|c|c|c|c|c|c|c|c|}
\hline \multicolumn{9}{|c|}{ Coefficients ${ }^{\mathrm{a}}$} \\
\hline \multirow[b]{2}{*}{ Model } & & \multicolumn{2}{|c|}{$\begin{array}{c}\text { Unstandardized } \\
\text { Coefficients }\end{array}$} & \multirow{2}{*}{$\begin{array}{c}\text { Standardized } \\
\text { Coefficients } \\
\text { Beta } \\
\end{array}$} & \multirow[b]{2}{*}{$t$} & \multirow[b]{2}{*}{ Sig. } & \multicolumn{2}{|c|}{ Collinearity Statistics } \\
\hline & & B & Std. Error & & & & Tolerance & VIF \\
\hline 1 & (Constant) & 6714.306 & 701.915 & & 9.566 & .000 & & \\
\hline & Nikkei & 216 & .060 & .522 & 3.605 & .000 & .107 & 9.345 \\
\hline & Dow Jones & .678 & .141 & 1.214 & 4.807 & .000 & .035 & 28.430 \\
\hline & BI Rate & -21938.0 & 8376.485 & -.245 & -2.619 & .010 & .256 & 3.899 \\
\hline & Fed Rate & -101037 & 8506.281 & -1.142 & -11.878 & .000 & .243 & 4.121 \\
\hline & IHSG & -1.646 & .292 & -1.401 & -5.645 & .000 & .036 & 27.466 \\
\hline
\end{tabular}

a. Dependent Variable: Nilai Tukar

Source: Processed Raw Data.

Based on the results of Table 3 and Table4 the regression equation model can be arranged as follows:

$$
\begin{gathered}
e_{2}=\sqrt{1-R^{2}}=\sqrt{1-0,744}=0,256 \\
Y_{2}=0,216 X_{1}+0,678 X_{2}-21.938 X_{3}-101.037 X_{4}-1,646 Y_{1}+0,256
\end{gathered}
$$

Where:

$Y_{1}=$ IHSG;

$X_{1}=$ Nikkei 225 Index;

$\mathrm{X}_{2}=$ Dow Jones Index;

$\mathrm{X}_{3}=\mathrm{BI}$ rate;

$\mathrm{X}_{4}=$ Fed rate . 
Table 4 shows that the Nikkei 225 index is sig. $0.000<0.05$ indicates that the Nikkei 225 index has a significant effect and has a positive effect on the exchange rate. The Dow Jones index with a sig value of $0.000<0.05$ indicates that the Dow Jones index has a significant effect and has a positive influence on the exchange rate. BI rate with sig. 0.010 $<0.05$ indicates that the $\mathrm{BI}$ Rate has a significant effect and has a negative effect on the exchange rate. Fed Rate with sig. $0.000<0.05$ indicates that the Fed Rate has a significant effect and has a negative effect on the exchange rate. While the IHSG with sig. $0.000<0.05$ indicates that the IHSG has a significant effect and has a negative effect on the exchange rate.

Based on the coefficient tables 3 and 4 , a path coefficient and the significance of the relationship between variables can be seen and summarized as presented as follows:

Table 5 - Summary of Path coefficients and the Significance of Intervariable Relations

\begin{tabular}{|c|c|c|c|c|c|}
\hline Reg & Coeff. & Std. Error & t-stat & P. Value & Sig. Level \\
\hline $\mathrm{X} 1 \rightarrow \mathrm{Y} 1$ & $-0,253$ & 0,017 & $-5,157$ & 0,000 & Significant \\
\hline $\mathrm{X} 2 \rightarrow \mathrm{Y} 1$ & 0,912 & 0,020 & 21,668 & 0,000 & Significant \\
\hline $\mathrm{X} 3 \rightarrow \mathrm{Y} 1$ & $-0,200$ & $2.228,424$ & $-6,732$ & 0,000 & Significant \\
\hline $\mathrm{X} 4 \rightarrow \mathrm{Y} 1$ & $-0,257$ & 2032,278 & $-9,538$ & 0,000 & Significant \\
\hline $\mathrm{X} 1 \rightarrow \mathrm{Y} 2$ & 0,522 & 0,60 & 3,605 & 0,000 & Significant \\
\hline $\mathrm{X} 2 \rightarrow \mathrm{Y} 2$ & 1,214 & 0,141 & 4,807 & 0,000 & Significant \\
\hline $\mathrm{X} 3 \rightarrow \mathrm{Y} 2$ & $-0,245$ & $8.376,485$ & $-2,619$ & 0,010 & Significant \\
\hline $\mathrm{X} 4 \rightarrow \mathrm{Y} 2$ & $-1,142$ & $8.506,281$ & $-11,878$ & 0,000 & Significant \\
\hline $\mathrm{Y} 1 \rightarrow \mathrm{Y} 2$ & $-1,401$ & 0,292 & $-5,645$ & 0,000 & Significant \\
\hline
\end{tabular}

Note: $Y_{1}=$ IHSG; $X_{1}=$ Nikkei 225 Index; $X_{2}=$ Dow Jones Index; $X_{3}=B I$ rate; $X_{4}=$ Fed rate .

Based on the standardized coefficient beta value and the probability value, the Nikkei 225 index results, Dow Jones index, BI rate, and Fed rate have a significant effect on IHSG in Indonesia in 2006-2015. This can be seen from the probability value of each variable of $0.000<0.05$ which means that $\mathrm{H} 0$ is rejected and $\mathrm{H} 1$ is accepted. For the Nikkei 225 (X1), BI rate $(\mathrm{X} 3)$ and Fed rate $(\mathrm{X} 4)$ index variables have a negative relationship to the $\mathrm{JCl}(\mathrm{Y} 1)$. As for the Dow Jones index (X2) has a positive effect on the IHSG (Y1).

The rising of the Nikkei 225 Index means that the performance of the Japanese economy is improving. As one of Indonesia's export destination countries, Japan's economic growth can drive Indonesia's economic growth through export activities and capital inflows, both direct investment and through the capital market (Sunariyah, 2006). However, in the year of this research period in 2009, the Japanese government reported that Japan's Gross Domestic Product (GDP) plummeted 12.7 percent during the October-December 2008. The economic downturn experienced by Japan even went far beyond the economic downturn in America States (Utama et al, 2015). In 2011, the Japanese Cabinet Office released Japan's gross domestic product down 0.9 percent in the first quarter compared to the previous three months.

The Japanese economy shrank at an annual rate of 3.7 percent in the first quarter of 2011. This resulted in the Japanese economy experiencing a recession (Erwin, in Utama et al, 2015). In the same year, when the Indonesian economy experienced quite high growth, the Japanese economy faced a severe ordeal following a barrage of natural disasters, namely the earthquake, tsunami, and nuclear reactor explosion. Successive disasters have also devastated the Japanese stock market. The Nikkei 225 index decreased dramatically to $1,232.78$ points (12.81\%) to the level of 8,387.71 (Nurul, 2011 in Utama et al, 2015). This study also supports the research of Sutanto et All (2013) and Deitiana et al (2009) which states that the Nikkei 225 index has a significant effect on the IHSG.

The Dow Jones index is moving up, indicating the performance of the United States economy, in general, is in a good position. With good economic conditions, it will drive the Indonesian economy through exports and the capital market (Sunariyah, 2006). Based on the results of the study it was found that the Dow Jones index had a significant effect on the IHSG, this background was that the United States was the destination of Indonesian exports, so that changes in US economic conditions that would be reflected in the Dow Jones Index 
would have an impact on the Indonesian economy through the IHSG. This study also supports the research of Darwati et al (2014) and Ernayani et all (2015) which states that the Dow Jones index has a significant and positive effect on the IHSG.

The variable $\mathrm{BI}$ rate and Fed Rate have a significant effect on the outcome of the Jakarta Composite Index. It is in the background that interest rates are determined by a country's monetary policy according to its economic situation. High-interest rates will prevent capital outflows, hamper economic growth and, consequently, hurt the economy because interest rates are one of the most important factors that directly affect economic growth. The rationale for that relationship between interest rates and stock market returns is that stock prices and interest rates are said to be negatively correlated (Upadhyay, 2016). This study also supports Ali (2014) which states that between interest rates and the stock market have a negative effect on research in Pakistan and Eita (2014) which states that there is a negative relationship between interest rates and the stock market in Namibia, which means monetary policy contraction through increased rates can reduce the stock market.

Based on the standardized coefficient beta and probability values, the Nikkei 225 (X1), Dow Jones (X2), BI rate (X3), Fed rate (X4), and IHSG (Y1) index have a significant effect on the exchange rate (Y2) in Indonesia in 2006-2015. This can be seen from the probability value of each variable of $0.000<0.05$ which means that $\mathrm{H} 0$ is accepted and $\mathrm{H} 1$ is rejected. The Nikkei 225 (X1) index and the Dow Jones index (X2) have a positive relationship with the exchange rate. As for the $\mathrm{BI}$ rate index variable, the fed and IHSG have a negative relationship with the exchange rate.

The Nikkei 225 index and the Dow Jones index have a significant effect on Exchange Rates. Ehrmann and Fratzscher (2004) investigated the effect of monetary policy on stock returns and found that stock market returns react negatively to interest rates. This study provides evidence that market returns stock reacts negatively to rising interest rates. This study also supports the research of Eita (2014) that there is a negative relationship between interest rates and stock market returns in Namibia, which shows that contractionary monetary policy through an increase in interest rates reduces the stock market again. Akdogu (2015) Brazil, the Czech Republic, Hungary, Indonesia, Korea, Malaysia, Peru, and Thailand are the results-oriented to a "stock oriented model" approach or "portfolio balanced approach", in that the stock price affects the exchange rate. On the other hand, data for Colombia supports the "traditional approach" that changes in exchange rates cause changes in stock prices.

$\mathrm{BI}$ rate and Fed Rate based on the results of research are significantly related to Exchange Rates. This is supported by Theory by the International Fisher Effect-IFE Theory of changes in interest rates relative to investment in foreign securities, which in turn will affect the demand and supply of foreign exchange. This will also affect currency exchange rates. The perfect relationship between relative interest rates and exchange rates between two countries is supported by research by Muhammad et al (2002) and Taha (2015).

$\mathrm{JCl}$ has increased, the exchange rate has appreciated which means the price of the exchange rate has decreased. This means that an increase in the $\mathrm{JCl}$ was also followed by the entry of fresh funds into Indonesia which had implications for the exchange of the Rupiah. In line with the Theory of Demand and supply proposed by Mankiw that in terms of demand the quantity of demand decreases when the price increases and the quantity of demand increases when the price decreases so that it is said that the quantity demanded is negatively related to price. This relationship between price and quantity demanded applies to most goods in the economy, and so real that economists call it the law of demand by assuming that other things are the same (cateris paribus. This is also supported by Akdogu's research et al (2005) concluded that Brazil, the Czech Republic, Hungary, Indonesia, Korea, Malaysia, Peru, and Thailand were the result-oriented to a "stock-oriented model" approach or "portfolio balanced approach", in that the stock price affected the exchange rate. another, data for Colombia supports a "traditional approach" that changes in exchange rates cause changes in share prices, and Akdogu et all (2005) concludes that Brazil, the Czech Republic, Hungary, Indonesia, Korea, Malaysia, Peru and Thailand results are oriented towards an approach "stock-oriented model" or "portfolio balanced approach", in which the stock price is 
influential exchange rate. On the other hand, data for Colombia supports the "traditional approach" that changes in exchange rates cause changes in stock prices.

Testing the effect is not using path analysis with the results of the study that there is only one variable that indirectly affects the Exchange Rate variable, the Nikkei 225 index, and for the other three variables namely the Dow Jones index, the BI Rate, and the Fed rate only has a direct effect. Thus, it is concluded that if $X 1, X 2, X 3, X 4$ have a significant effect on $Y 1$ and $Y 2$, no matter whether $X 1, X 2, X 3, X 4$ through $Y 1$ to $Y 2$ are significant or not significant, the mediating variable plays a role, in this case, the mediating variable partially.

\section{RESEARCH LIMITATIONS}

This study analyzes whether there are influences of factors that affect the exchange rate in Indonesia by using the IHSG factor as an intermediate variable. His research takes stock markets in the United States and Japan, as well as Indonesian and American interest rates as the dependent variable. It would be better if the focus of the research could be done in one country but by explaining the overall economic factors such as export-import, and investment.

\section{REFERENCES}

1. Abdalla, I. S., \& Murinde, V. (1997). Exchange Rate and Stock Price Interaction in Emerging Financial Market: Evidence on India, Korea, Pakistan, and the Philipines. Applied Financial Economic, Vol. 7, 25-35.

2. Akdogu. 2016. Interaction between Stock Prices and Exchange Rate in Emerging Market Economies. Research in World Economy Vol. 7, No. 1.

3. Appa Yuni, 2014. Pengaruh Inflasi and Kurs Rupiah /Dolar Amerika Terhadap Indeks Harga Saham Gabungan (IHSG) di bursa Efek Indonesia (BEI).

4. Arifin, S. (1998). Efektifitas Kebijakan Suku Bunga Dalam Rangka Stabilisasi Rupiah Di Masa Krisis. Buletin Ekonomi Moneter and Perbankan,1(3), 1-26.

5. Bank Indonesia. Moneter 1997-1999. Laporan.

6. Chiarella C. and Gao.S, 2004." The value of the S\&P $500-A$ Macro View of the Stock market Adjustment Process". Global Finance Journal, 15: 171-196.

7. Kuncoro Mudrajad. 2015. Indikator Ekonomi: UPP Stim YKPN Yogyakarta.

8. Kurniasari, Sitinjak, dkk. 2003. Indikator-indikator Pasar Saham and Pasar Uang Yang Saling Berkaitan Ditijau Dari Pasar Saham Sedang Bullish and Bearish. Jurnal Riset Ekonomi and Manajemen. Vol. 3 No. 3.

9. Madura. 2006. International Corporate Finance. Terjemahan. Buku 1. Salemba Empat.

10. Mankiw, N. Gregory, 2000. Teori Makro Ekonomi. Edisi Keempat. Erlangga.

11. Nachrowi Djalal Nachrowi. 2007. Prediksi IHSG dengan Model Garch and Arima. Vol.7, No.2. Jurnal Ekonomi and Pembangunan Indonesia. Universitas Indonesia.

12. Raz F Arisyi et all. 2012. Krisis Keuangan Global and Pertumbuhan Ekonomi: Analisa dari Perekonomian Asia Timur. Buletin Ekonomi Moneter and Perbankan.

13. Ruhendi \& Arifin, Johan. 2003. Dampak Perubahan Kurs Rupiah and Indeks Saham Dow Jones di New York Stock Exchange Terhadap Indeks Harga Saham Gabungan di BEJ. Jurnal Wahana Vol. 6 hal 45-55.

14. Serpil Kahraman Akdogu1 \& Ayse Ozden Birkan, 2016. Interaction between Stock Prices and Exchange Rate in Emerging Market Economies. Research in World Economy Vol. 7, No. $1 ; 2016$.

15. Sitinjak, Elyzabeth Lucky Maretha and Widuri Kurniasari. 2003. Indikator Pasar Saham and Pasar Uang Yang Saling Berkaitan Ditijau Dari Pasar Saham Sedang Bullish and Bearish. Jurnal Riset Ekonomi and Manajemen. Vol. 3 No. 3.

16. Sunariyah, 2006, Pengantar Pengetahuan Pasar Modal, Edisi Kelima, UPP STIM YKPN.

17. Upadhyay, Arcana. 2016. Causality Relationship between Interest Rate and Stock Returns in India - An Analytical Study. Journal of Management Sciences and Technology. Research Scholar, Banaras Hindu University Varanasi. India. 